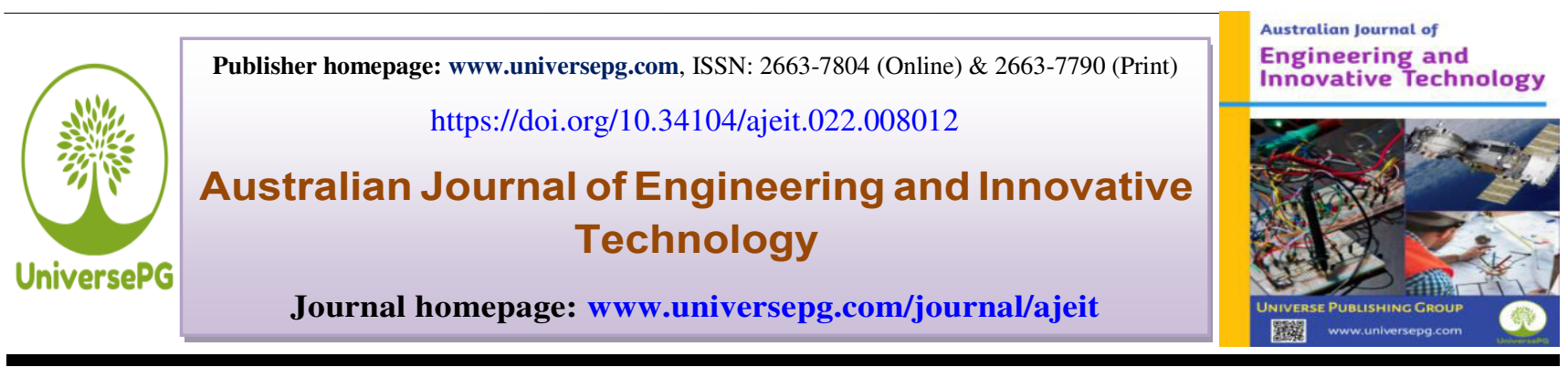

\title{
Design and Simulation of a Hybrid Microgrid System for Remote Areas of Kuakata, Bangladesh
}

\author{
Md. Rubel Ali Biswash ${ }^{1}$, Md. Moniruzzaman², Md. Sarowar Hossain Chowdhury ${ }^{2}$, Dipa Saha ${ }^{2}$, Md \\ Motasim Billah', Al Helal' ${ }^{2}$, and S.M. Abir Hasan ${ }^{2}$ \\ ${ }^{1}$ Atomic Energy Centre, Shahbag, Dhaka, Bangladesh; ${ }^{2}$ Engineering Division, Bangladesh Atomic Energy Commission, \\ West Agargaon, Dhaka, Bangladesh. \\ *Correspondence: rubelalibiwas16@gmail.com (Md. Rubel Ali Biswash, Engineer-EEE, E\&G.S Division, Atomic Energy \\ Center, Shahbagh, Dhaka).
}

\begin{abstract}
Electrification of the rural areas which are located far from the grid is comparatively more expensive due to the high cost associated with power transmission. Renewable energy-based hybrid micro-grid systems can be a cost-effective method for the supply of electricity in these remote areas. This study aims at assessing the technical and economic viability of a hybrid micro-grid system for rural areas of Bangladesh. A hybrid microgrid system consisting of PV solar cells, wind turbine, and Diesel Generator has been designed for remote regions of Kuakata, Patuakhali. A combination of different technologies capable of generating electricity has been used to ensure the reliable and continuous supply of electrical power. HOMER, simulation software, has been used for optimizing multiple energy sources to maintain an uninterrupted supply of power in a cost-effective way. Finally, cost analysis and consistency checking have been done by another simulation software called RETScreen.
\end{abstract}

Keywords: Renewable energy, Microgrid System, Kuakata, Simulation, Power, HOMER, and RETScreen.

\section{INTRODUCTION:}

The use of fossil fuel for power generation has significantly increased global air pollution, water pollution, coastal pollution, deforestation and global climate deterioration over the centuries. Oil, natural gas, and coal together constitute $80 \%$ of global energy consumption (World Resource Institute, 2006). World Bank reported that 2.4 billion people rely on traditional energy sources, while 1.6 billion people do not have access to electricity (World Bank, 2004). From statistics, the projected demand for electricity in developing countries is increasing by $4.6 \%$ annually (Ibrahim et al., 2002). Over the last few decades, a decline in fossil fuel reserves has been observed worldwide. Based on current reserves and consumption rates, the globe can maintain coal for 122 years, oil for 42 years, and natural gas for 60 years (Lior, 2009). Therefore, it is vital to increase the use of renewable UniversePG I www.universepg.com energy reducing the dependency on fossil fuel.

In Bangladesh, natural gas is the major energy source contributing approximately $51 \%(10,450 \mathrm{MW})$ to the total power generation (Bangladesh Power Development Board, 2020). The present share of renewable energy in Bangladesh is only $1.5 \%$ (Electricity sector in Bangladesh) but the government's goal is to generate $10 \%$ of the total power from renewable sources. Hybrid microgrid system developed by the combination of available renewable energy resources can be useful for this purpose. The feasibility of a hybrid microgrid system is dependent on the availability of solar and wind energy. The coastal area of Bangladesh has an average wind speed of $4-6 \mathrm{~m} / \mathrm{s}$, which indicates that wind-based power plants can be implemented in the potential sites (Islam, 2003) but a standalone wind power system cannot ensure consistency 
of power supply. Hence PV-Wind-Solar type hybrid microgrid system has been considered in this study. The hybrid microgrid has been designed for the remote areas of Kuakata based on available wind and solar resources there. Kuakata is a sub district of Patuakhali, located in the coastal region which makes it suitable for wind-based power systems. Homer is simulation software that is used for designing the hybrid model of a power system (Sattar et al., 2021).

Financial analyses including Cost of Energy (COE), Net Present Cost (NPC), Payback year, cash flow analysis can also be done by HOMER. Another software that aids decision-makers in determining the technical and financial feasibility of renewable energy projects is RET Screen. Conventional energy projects may be modeled and compared against sustainable alternatives in this software.

\section{METHODOLOGY:}

The basic structure of the hybrid micro-grid system used in this study is given in Fig. 1. The system consists of PV Panel, wind turbine, diesel generator, Battery and Converter. There are two buses in the system; AC and DC buses. The output energy of solar $\mathrm{PV}$ is stored in a battery which is on the DC bus side. To convert AC from DC, the converter is used. Wind and diesel generators are operating at AC bus. Output power can be drawn from the ac bus.

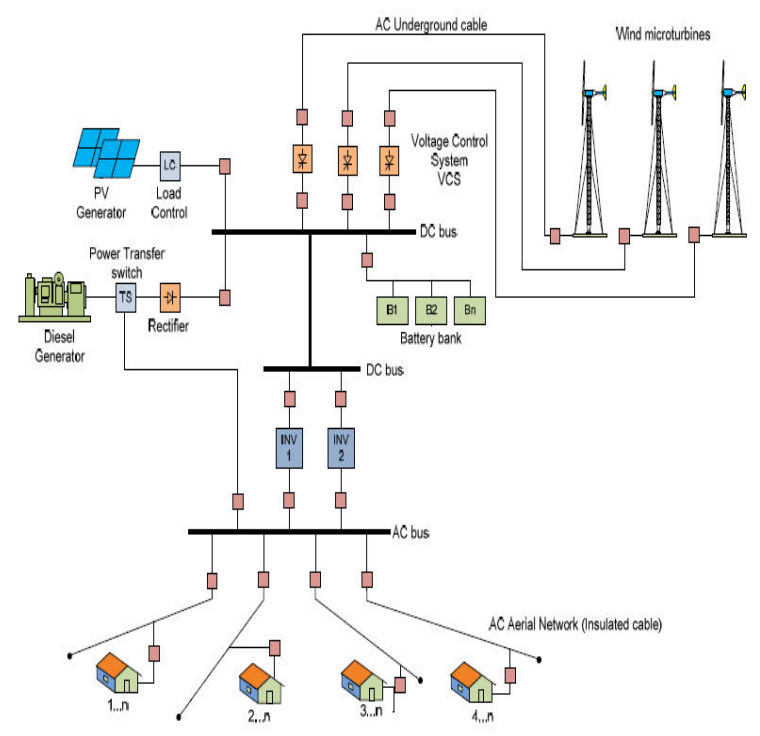

Fig. 1: The schematic diagram of hybrid pv-wind-diesel system (Monir et al., 2007).

In this study, Design and optimization for the best hybrid model have been carried out by HOMER. The operating principle of HOMER is given below in Fig. 2.

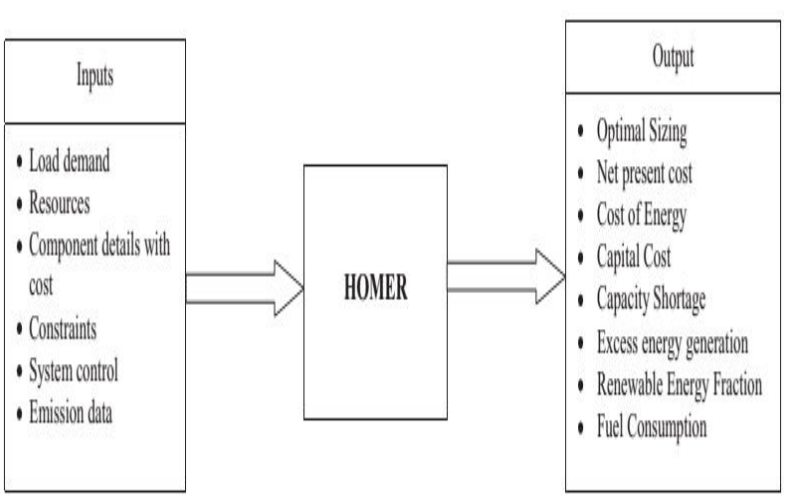

Fig. 2: Block diagram of HOMER.

The load demand, resources, and some other components detail with cost have been input in HOMER. The usual load of a small remote region having 500 homes, one school, one market with 20 shops, one dairy farm, and 30 acres of agricultural land requiring irrigation has been considered. The load curve plotted from the assumed data is given in Fig. 3 .

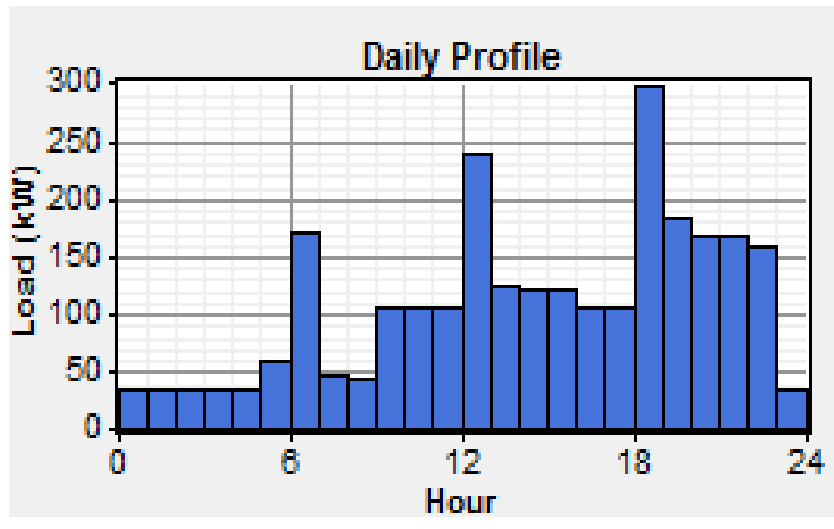

Fig. 3: The daily load curve.

Solar and wind resource available at Kuakata, Patuakhali that has been input to HOMER are shown in Fig. 4.

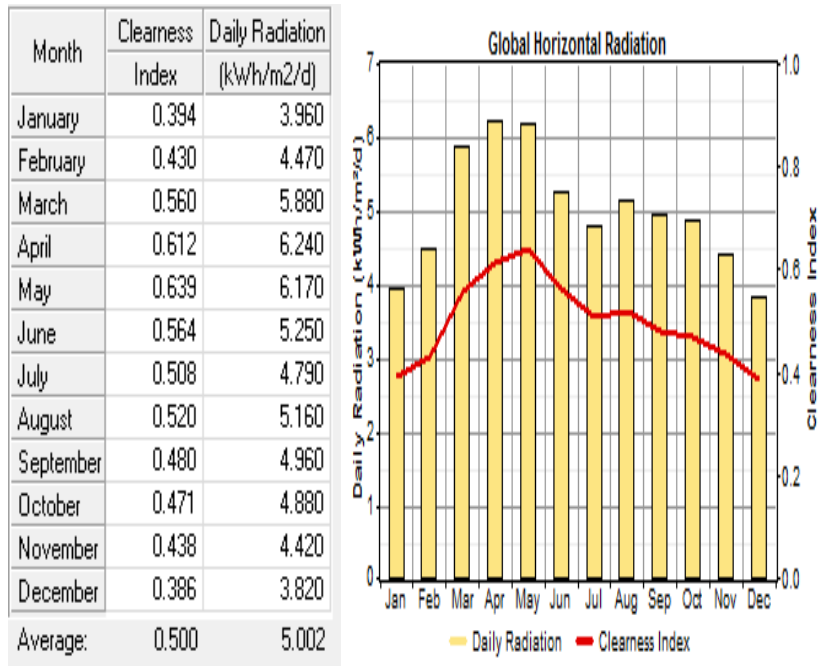

Fig. 4: Global Horizontal Radiation. 


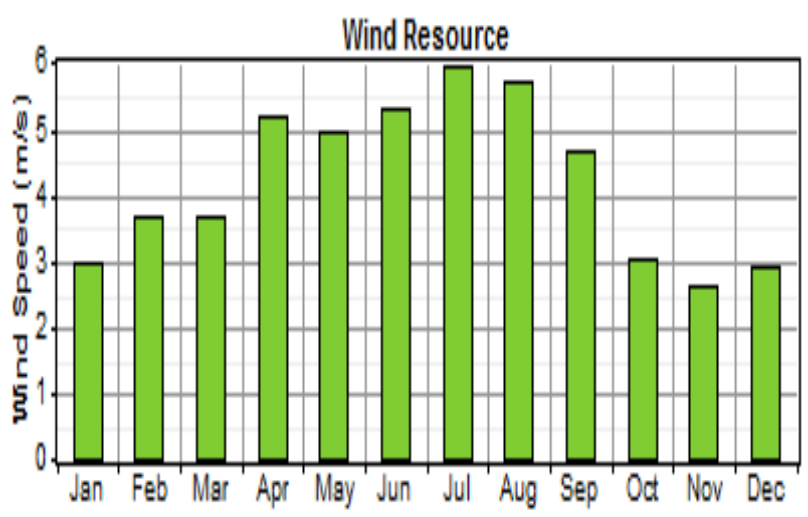

Fig. 5: Monthly solar radiation and wind speed at Kuakata (Islam, 2007).

HOMER eliminated all infeasible systems and presented the results in ascending order of net present cost (NPC). The economic feasibility of the most optimum model found from HOMER was checked by RETscreen. Fig. 6 shows the block diagram of RETScreen.

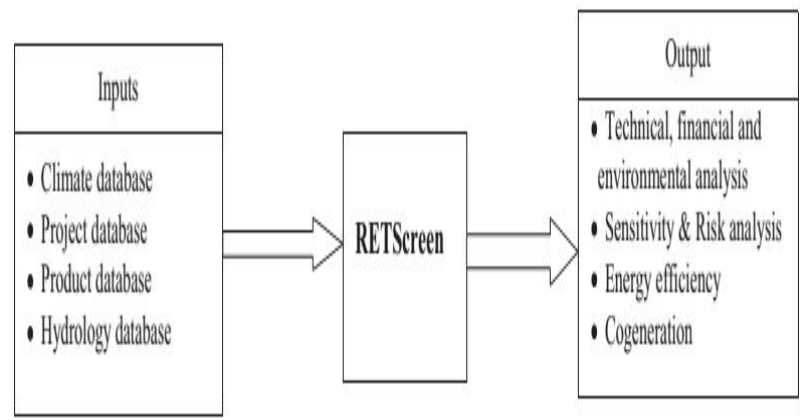

Fig. 6: Block diagram of RETScreen.

\section{RESULTS AND DISCUSSION:}

The most optimized hybrid PV-Wind-Diesel power system found from HOMER based on available solar and wind resources of Kuakata is schematically presented in Fig. 7.

\begin{tabular}{|c|c|c|c|}
\hline Equipment to conside & Add/Remove & PV Array & $200 \mathrm{~kW}$ \\
\hline & & Wind turbine & 3 Enercon E33 \\
\hline & & Generator 1 & $125 \mathrm{~kW}$ \\
\hline Enerc & Dil & Generator 2 & $50 \mathrm{~kW}$ \\
\hline Generator 1 & & Battery & $\begin{array}{l}300 \text { Copy of } \\
\text { Hoppecke } 24 \\
\text { OPzS } 3000\end{array}$ \\
\hline & 用 & Inverter & $300 \mathrm{~kW}$ \\
\hline 3 & $H \overline{3000}$ & Rectifier & $300 \mathrm{~kW}$ \\
\hline Generdor 2 & & $\begin{array}{l}\text { Dispatch } \\
\text { strategy }\end{array}$ & Cycle Charging \\
\hline
\end{tabular}

Fig. 7: System architecture and specification.

HOMER analyzed and optimized different hybrid models and showed the most feasible one at the top. Here four possible models have been presented in as- cending order of cost of energy (COE).Two of them are Wind-diesel models and another two are PVWind-Diesel models. As shown in Fig. 8. Wind-Diesel model with one Generator is the least preferable in terms of cost-effectiveness whereas the PV-WindDiesel model with two generators is the most viable one (Mamun et al., 2020).

\begin{tabular}{|c|c|c|c|c|c|c|c|}
\hline 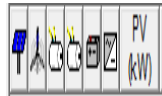 & 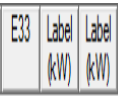 & H3OOO $\mid \begin{array}{ll}C_{n} \\
\text { Wh }\end{array}$ & 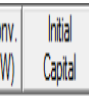 & 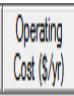 & 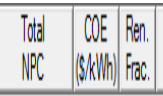 & $\begin{array}{l}\text { Deed } \\
\text { I. }\end{array}$ & 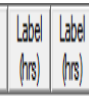 \\
\hline 2010 & 31650 & 303 & 20011,0560 & 196525 & 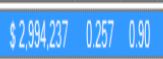 & Q6010 & 281 \\
\hline 人o⿰日月 & 312570 & 403 & 845,00 & 1750,44 & 331018256 & & 12792464 \\
\hline 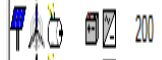 & 3200 & 303 & $300 \$ 1,097,50$ & 160,47 & $33,255,580.0270 .08$ & & 1215 \\
\hline 略 & 3200 & 2031 & $\$ 767,30$ & 204,55 & $83,381,1150.02007 .8$ & 128279 & 1900 \\
\hline
\end{tabular}

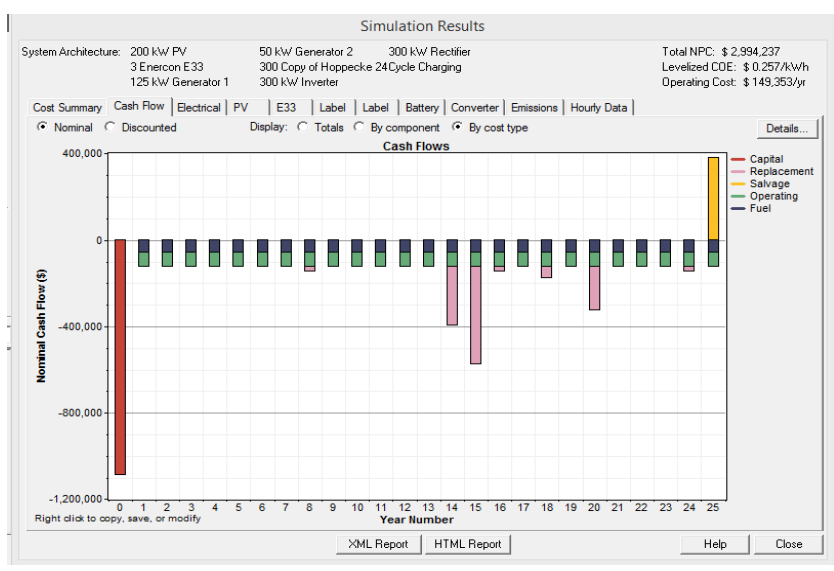

Fig. 8: Optimization result with economic analysis.

The most optimized model is shown at the top consisting of 2 Diesel generators with $125 \mathrm{~kW}$ and $50 \mathrm{~kW}$ capacities, 3 Enercon E33 wind turbines, and a 200 $\mathrm{kW}$ PV array. The percentages of electrical energy production in different technologies of this system are: PV16\%, wind turbine $74 \%$ and Diesel Generator $10 \%$. The renewable fraction of this model is 0.90 . Details of electrical energy output from the simulation result are shown in Fig. 9.

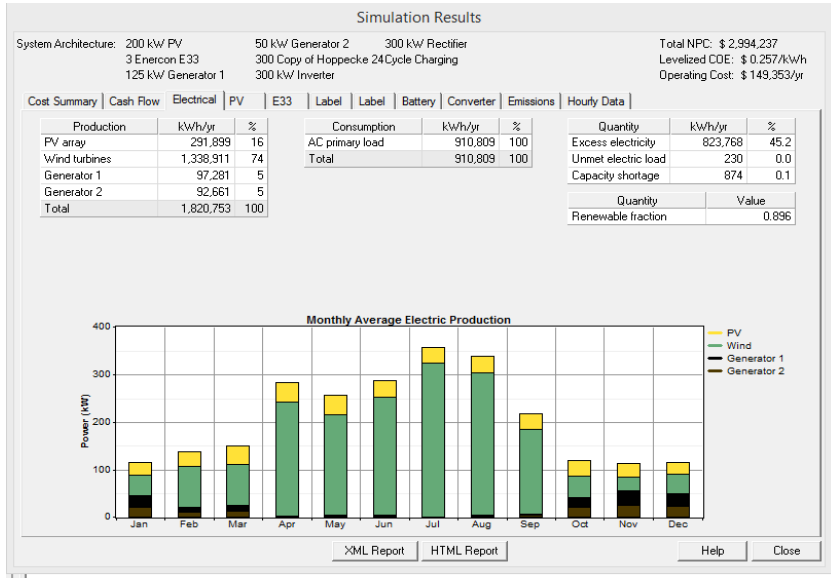

Fig. 9: The electrical energy output from different technology. 
The economic viability of the most optimized model checked by RETScreen software seems promising. For a selling rate of 15 taka per $\mathrm{kWh}$, the payback year has been found to be 3.2 years. The Cumulative cash flow for this selling price is shown in Fig. 10.

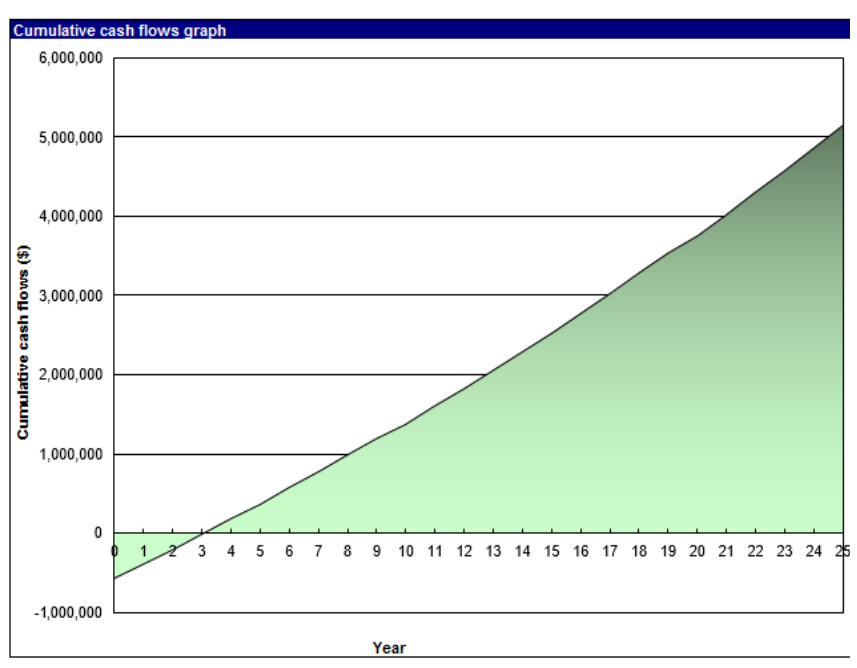

Fig. 10: Cumulative cash flows graph from RETScreen.

\section{CONCLUSION:}

The hybrid system can bring enormous benefits to the remote areas where there is a severe crisis of reliable supply of electricity. The system is associated with very low emissions as the nonrenewable fraction of the system is only 0.10 . The results indicate that the optimized wind-PV-diesel hybrid system is more cost-effective in terms of Net Present Cost (NPC) and Cost of Energy (COE) in comparison to the winddiesel system. For a unit price of 15 taka payback year is only 3.2 years which indicates that the system is economically feasible. If implemented properly this system can be helpful to promote the socio-economic development of the local people.

\section{ACKNOLEDGEMENT:}

We are grateful to Md. Rabiul Islam for his valuable suggestion and support throughout the development of this article.

\section{CONFLICTS OF INTEREST:}

The authors state that there is no potential conflict of interest in publishing this research article.

\section{REFERENCES:}

1) Bangladesh Power Development Board (BPDB), (2020).

http://www.bpdb.gov.bd/bpdb/
2) Bangladesh Power Development Board (BPDB), (2020). Power Generation Units (Fuel Type Wise). Retrieved September 17, from http://www.bpdb.gov.bd/bpdb/index.php?option $=$ com_content $\&$ view $=$ article $\& \mathrm{id}=150 \&$ Itemid $=$ $\underline{16}$

3) British Petroleum (BP), (2020). Statistical review of world energy, 2009

https://www.bp.com/en/global/corporate/energy -economics/statistical-review-of-world-energy.h $\underline{\mathrm{tml}}$

4) Electricity sector in Bangladesh from http://en.wikipedia.org/wiki/Electricity sector in_Bangladesh

5) Islam, K., "Study of Wind Power Pumping Set for Bangladesh". MechanicalEngineering Dept. M.Sc. Engineering Thesis in BUET. https://doi.org/10.13140/2.1.2974.4326

6) Islam. M, (2015). Assessment of Renewable Energy Resources of Bangladesh, 1. Retrieved 28, 2015.

https://www.researchgate.net/publication/23742 1329 Assessment of Renewable Energy Reso urces_Of_Bangladesh

7) Lior, N., "Energy resources and use: the present situation and possible paths to the future", Energy, 22, https://doi.org/10.1016/j.energy.2007.09.009

8) Mamun AMA, Islam T, Siam MMS, and Kabir ME. (2020). Development of smart librarian with the virtual assistant (PRIMO), Aust. J. Eng. Innov. Technol., 2(4), 54-65. https://doi.org/10.34104/ajeit.020.054065

9) M. Ibrahim, M. Anisuzzaman, S. Kumar, \& S. C. Bhattacharya, (2002). "Demonstration of PV micro-utility system for rural electrification”, Solar Energy, 72(6), pp. 521-530. https://doi.org/10.1016/S0038-092X(02)000300

10) Monir, S.S., Ahmed, M., and Alam, M. (2007). "Fe- asibility of Wind Energy Project in Bangladesh". Mechanical Engineering Department, M.Sc. Engineering Thesis in BUET. https://doi.org/10.13140/2.1.2974.4326

11) Power Division. Ministry of Power, Energy and Mineral Resources, (2021). Government of the People's Republic of Bangladesh.

12) Sattar S, Alam MJ, Mawla Y, Rahman MA, and Mamun MAA. (2021). Design and development of a wireless robotic system for Radi- 
ation detection and measurement, Aust. J. Eng. Innov. Technol., 3(4), 57-63.

https://doi.org/10.34104/ajeit.021.057063

13) Van der Zwaan, B., \& Rabl, B., (2003). Prospects for PV: a learning curve analysis. Solar Energy, 74, pp.19-31.

https://doi.org/10.1016/S0038-092X(03)00112$\underline{9}$
14) World Bank, Renewable Energy for Rural Development, (2004). The World Bank Group: 1818 H Street, NY Washington, DC 20433.

15) World Resource Institute, Fossil Fuel Consumption and its implications, (2006). Retrieved December 28, 2021.

http://www.wri.org/stories/2006/11/\%20fossil\%20fuel-consumption-\%20and-its-implications

Citation: Biswash MRA, Moniruzzaman M, Chowdhury MSH, Saha D, Billah MM, Helal A, and Hasan SMA. (2022). Design and simulation of a hybrid microgrid system for remote areas of Kuakata, Bangladesh. Aust. J. Eng. Innov. Technol., 4(1), 08-12. https://doi.org/10.34104/ajeit.022.008012 @ @ 